\title{
Evaluation of Deer Habitat on a Nutritional
} Basis

\author{
O. C. WAllmo, L. H. CARPENTER, W. L. REgElin, R. B. GILl, AND D. L. BAKER
}

Highlight: Protein and energy requirements of deer and supplies of these nutrients in native forage are synthesized into a model to estimate carrying capacity of seasonal ranges of a migratory mule deer population in north central Colorado. The model indicates that summer forage will support many times the number of deer present, but winter forage will not sustain deer at any population level. Instead, duration and severity of winter determine the length of time deer can survive on these ranges. Habitat evaluation based on quantification of nutrient supplies and their availability offers a more logical alternative for evaluating deer winter ranges than traditional methods based on measurements of twig lengths of so-called "key" species.

Several range evaluation procedures have been adopted in North America to help managers keep big game populations and their habitat in balance, but none of them provide a demonstrable relationship between measured attributes of habitat and its carrying capacity. Moen (1973) outlined a concept for the estimation of carrying capacity based on protein and energy requirements, but regretted that the required data (p. 334) "are largely unavailable for wild ruminants." The basis for this concept is more fully elaborated by Robbins (1973).

We suggest that existing knowledge of the nutritional requirements of deer (Odocoileus spp.) permits realistic habitat evaluation based upon forage supplies and forage quality, and that data pertinent to specific herds and ranges can be acquired. The model presented uses information obtained from the Middle Park Deer Ecology Study, a cooperative program of the Colorado Division of Wildlife, the Rocky Mountain Forest and Range Experiment Station, and Colorado State University concerned with the ecology of Rocky Mountain mule deer $(O$. hemionus hemionus).

\section{Study Area and Deer Population}

Middle Park, in north central Colorado, is the headwaters basin of the Colorado River (Gilbert et al. 1970). The entire basin encompasses about 600,000 ha and ranges in elevation from 2,200 to $4,500 \mathrm{~m}$. It contains a virtually discrete deer herd because encircling high mountains and winter snow accumulation effectively prevent ingress and egress. Normally, most of the deer spend the period from early June to mid-November (160-170 days) on about 500,000 ha in the subalpine

Wallmo and Regelin are, respectively, principal wildlife biologist and range scientist, Rocky Mountain Forest and Range Experiment Station, U.S. Department of Agriculture, Forest Service, with central headquarters maintained at Fort Collins, in cooperation with Colorado State University . Carpenter is wildlife researcher, Colorado Division of Wildlife, Kremmling. Gill is big game research leader, and Baker, research technician, Colorado Division of Wildlife, Fort Collins.

Colorado Division of Wildlife Operations were conducted under Pitman-Robertson Project W-38-R.

Manuscript received March 23, 1976

forest zone. The period of summer range occupancy is largely determined by snow. Deer remain on this range as long as weather permits and descend only as far as snow depth requires (Gilbert et al. 1970).

The area occupied by deer in early winter consists of about 100,000 ha and includes the forest-mountain shrub ecotone down through the big sagebrush zone. This range normally is occupied for about 60 days from mid-November to mid-January.

In most years, January storms finally crowd deer into about 4,000 ha of southerly facing slopes and wind-swept ridges at lowest elevations, where they remain until about mid-March or about 60 days. Accessible range then begins to expand as the snow melts. The resurgence of plant growth alleviates winter nutritional stresses.

The winter deer population has varied between about 7,000 and 11,000 the past 8 years. Herd composition samples for that period provide the basis for a representative herd (Table 1) consisting of 10,200 deer in summer, exclusive of fawns, 10,000 in early winter, including fawns, and 9,000 in late winter. This converts to approximate stocking rates of about $45 \mathrm{ha} /$ deer in summer, $10 \mathrm{ha} /$ deer in early winter, and $0.44 \mathrm{ha} /$ deer in late winter. Information on the size and composition of the population was obtained from Gill $(1969,1970)$.

\section{Forage Quantity and Quality}

Deer forage species were determined by observing forage selections of tame, trained deer grazing in selected areas occupied seasonally by wild deer (Gill and Wallmo 1973; Wallmo et al. 1972). Standing forage crop was estimated on selected areas of summer, early-winter, and late-spring ranges (Carpenter 1972; Wallmo et al. 1972). The precision of these estimates is established only for the sites sampled. Estimates applicable to large range areas will be required for implementation of the model. The following derivations of usable forage do not include all of the big sagebrush (Artemisia tridentata) herbage because, as explained later, this species can comprise no more than about $20 \%$ of the diet of deer without impairing digestion.

Area: ha $\times 10^{3}$

Average total forage per ha $(\mathrm{kg})$ sagebrush

other

Average usable forage per ha $(\mathrm{kg})$ (20\% sagebrush, $80 \%$ other)

Total usable forage $\left(\mathrm{kg} \times 10^{6}\right)$

If $500=80 \%, 625=100 \%$.

If $400=80 \%, 500=100 \%$.

Species that comprised at least $90 \%$ of the diet in each of nine seasonal periods (Fig. 1) were analyzed for several nutritionrelated attributes. Methods for determining crude protein (CP) were from A.O.A.C. (1955), cell wall constituents (CWC) 


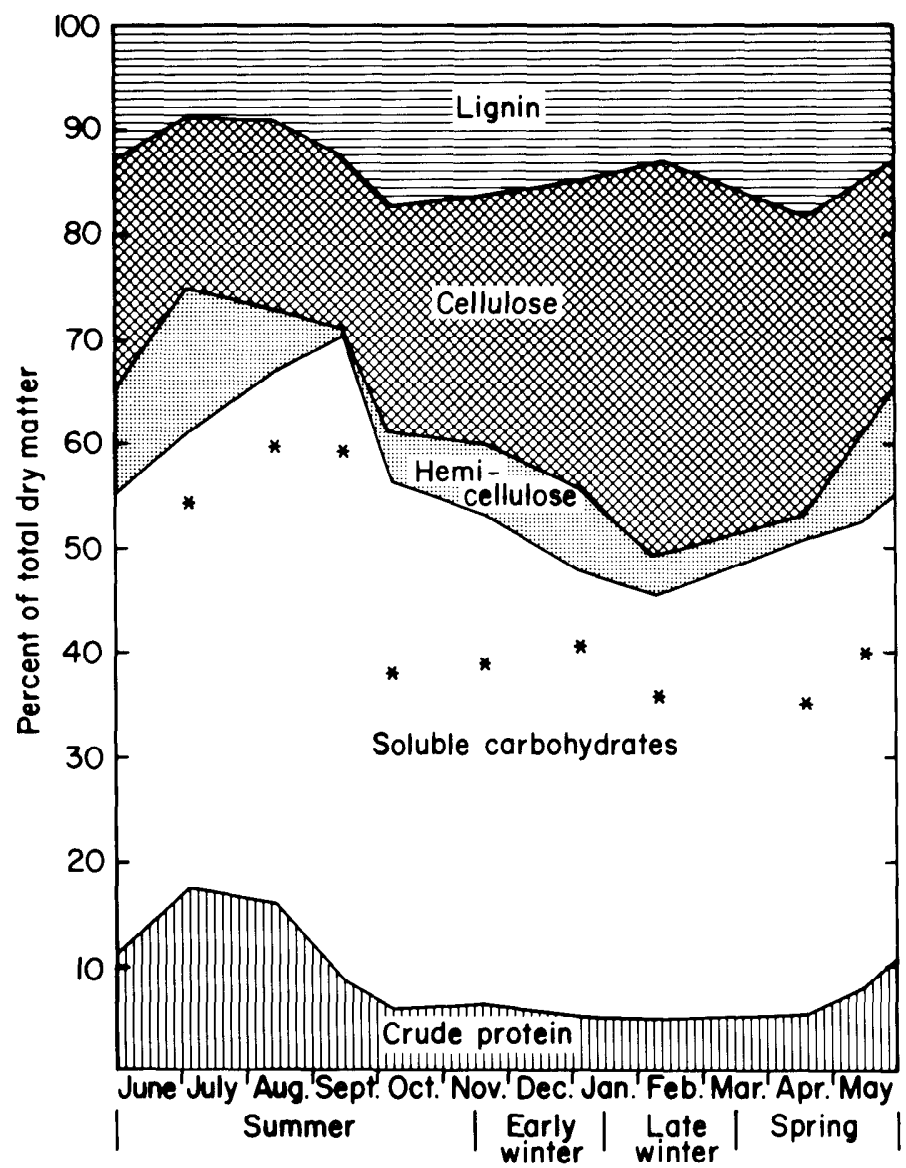

Fig. 1. Several components and dry matter digestibility $\left(^{\star}\right)$ of seasonal forages (means of plants that comprised $90-95 \%$ of the seasonal diets not weighted for diet composition).

from Van Soest and Wine (1967), acid detergent fiber (ADF) and lignin (ADL) from Van Soest (1963), and in vitro dry matter digestibility (DMD) from Tilley and Terry (1963) as modified by Pearson (1970). Cellulose content was inferred as the difference between ADF and ADL, hemicellulose as the difference betwen CWC and ADF, and soluble cell contents as the difference between $\mathrm{CWC}$ and $\mathrm{CP}$.
Summer forages were high and winter forages low in the more digestible components-protein, starches and sugars, and hemicellulose (Fig. 1, Table 2). The high average cellulose content of winter forages is attributable mainly to grasses: $37-47 \%$ cellulose vs $19-32 \%$ in deciduous shrubs. Deciduous shrubs were high in lignin content: $18-25 \%$ vs $5-6 \%$ in grasses. Average digestibility of grasses (Agropyron smithii, A. spicatum, Bouteloua gracilis, Poa fendleriana, and Stipa pinetorum) was $42 \%$ in February and that of browse twigs 34\% (Amelanchier alnifolia, Purshia tridentata, and Symphoricarpos oreophilus).

The gross energy content of forages averages around 4.5 $\mathrm{kcal} / \mathrm{g}$ (Cook 1971; Mautz et al. 1974; Swift 1957). Comparable values were obtained in the Middle Park study: summer mean 4.3 , winter 4.5 . There is nearly $1: 1$ relationship between the percent digestibility, in vivo, of total dry matter and digestible energy (Mautz et al. 1974; Moir 1961; Rittenhouse et al. 1971; Robbins 1973). Metabolizable energy (ME) is quite constantly about $85 \%$ of digestible energy (DE) (Brody 1945; Mautz et al. 1974; Smith 1971; Thompson et al. 1973). Scales et al. (1974) and McLeod and Minson (1974) demonstrated that in vitro and in vivo digestion coefficients are highly correlated and approximately equivalent to the range of $40-60 \%$. In vitro digestion coefficients for a ration fed to two white-tailed deer (Odocoileus virginianus) by Ruggiero and Whelan (1976) ranged from 86.3 to $99.7 \%$ of corresponding in vivo coefficients, with a mean of 94.7\%. It can be inferred, then, that: (1) less ME is obtained from the winter diet in Middle Park, and (2) the more digestible species of winter forages yielded more energy to the deer than less digestible species.

Evaluation of the nutritional contribution of big sagebrush is less obvious. Big sagebrush has a higher gross energy content $(>5 \mathrm{kcal} / \mathrm{g}$ ) largely because of essential oils which are not biological nutrients (Moen 1973;138). In our in vitro digestions of big sagebrush, percent DMD was relatively high (64 and 54\% in January and February), but much of the oil was lost in preparatory oven drying and grinding. The ingestion of substantial amounts of big sagebrush has been shown to inhibit digestive functions (Ward and Nagy 1966; Nagy et al. 1964). In pasture grazing studies in Middle Park, the consumption of big sagebrush increased (up to $30 \%$ of the diet) as other forage was

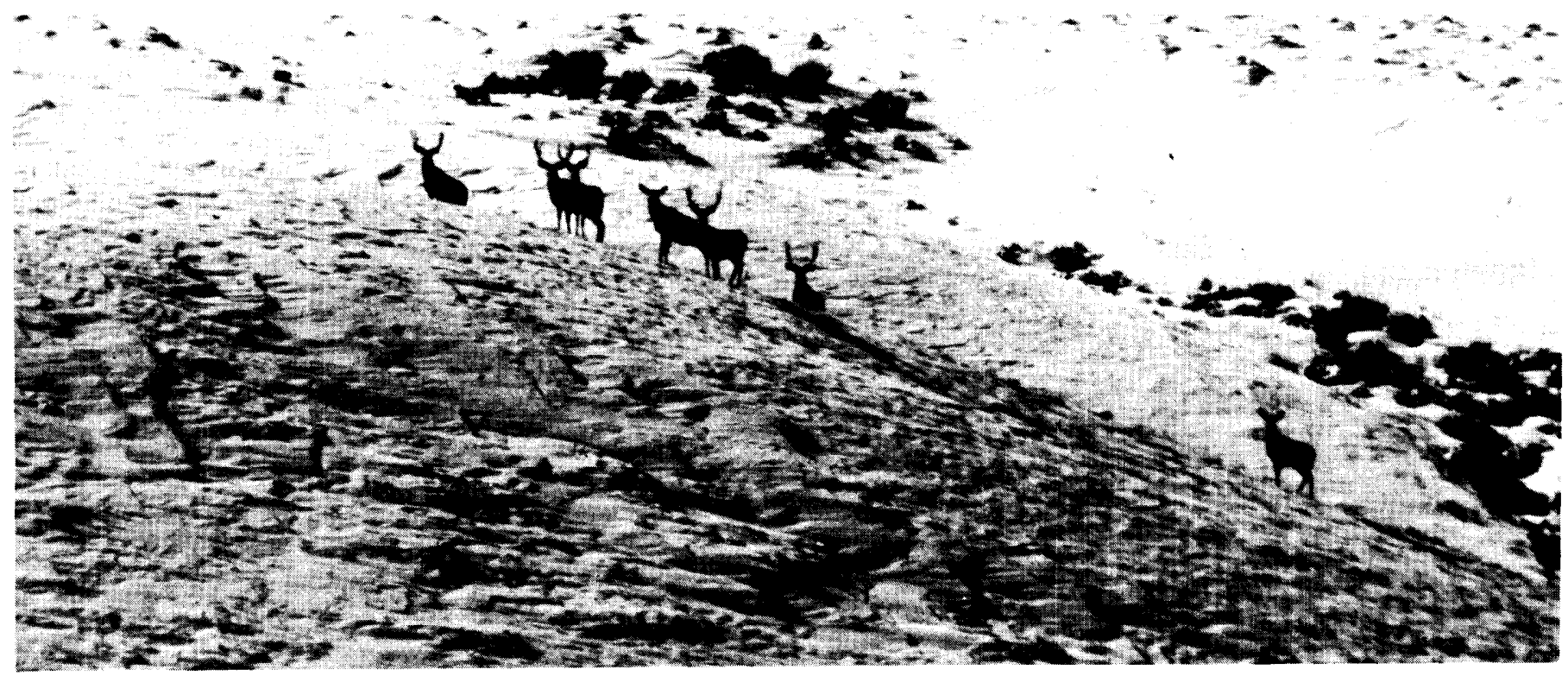

Critical deer winter range in Middle Park during January. 
Table 1. Deer means for estimation of carrying capacity.

\begin{tabular}{|c|c|c|c|c|c|c|c|c|}
\hline \multirow{3}{*}{$\begin{array}{c}\text { Season } \\
\text { and herd } \\
\text { components }\end{array}$} & \multirow{3}{*}{$\begin{array}{l}\text { Total } \\
\text { number } \\
\text { of deer }\end{array}$} & \multicolumn{2}{|c|}{ Weight (W) } & \multirow{2}{*}{\multicolumn{2}{|c|}{$\begin{array}{c}\text { Activity } \\
\text { metabolic rate }\end{array}$}} & \multirow{2}{*}{\multicolumn{2}{|c|}{ Intake $^{2}$}} & \multirow{3}{*}{$\begin{array}{c}\text { Protein } \\
\text { require- } \\
\text { ment } \\
(\%)\end{array}$} \\
\hline & & \multirow{2}{*}{$\begin{array}{c}\text { Body } \\
(\mathrm{kg})\end{array}$} & \multirow{2}{*}{$\begin{array}{c}\text { Metabolic } \\
\left(\mathbf{W}^{0.73}\right)\end{array}$} & & & & & \\
\hline & & & & $\times \mathrm{BMR}^{\prime}$ & kcal/day & $\mathrm{g} / \mathrm{kg} / \mathrm{day}$ & $\mathrm{kg} / \mathrm{day}$ & \\
\hline \multicolumn{9}{|l|}{$\begin{array}{l}\text { Summer"3 } \\
\text { Yearlings: }\end{array}$} \\
\hline Females & 1,500 & 64 & 22 & 2.0 & 3,080 & 31 & 2.0 & 15 \\
\hline Males & 1,200 & 70 & 24 & 2.0 & 3,360 & 31 & 2.2 & 15 \\
\hline \multicolumn{9}{|l|}{ Adults: } \\
\hline Females & 5,000 & 70 & 24 & 2.3 & 3,864 & 21 & 1.5 & 17 \\
\hline Males & 2,500 & 93 & 30 & 2.0 & 4.200 & 21 & 2.0 & 15 \\
\hline Total & 10,200 & & & & & & & \\
\hline \multicolumn{9}{|l|}{ Early winter } \\
\hline Fawns & 3,500 & 25 & 11 & 2.0 & 1,540 & 31 & 0.8 & 10 \\
\hline $\begin{array}{l}\text { Yearlings: } \\
\text { Females }\end{array}$ & 1,200 & 65 & 23 & 2.0 & 3.220 & 24 & 1.6 & 7 \\
\hline Males & 900 & 85 & 28 & 2.5 & 4,900 & 24 & 2.0 & 7 \\
\hline \multicolumn{9}{|l|}{ Adults: } \\
\hline Females & 3,300 & 73 & 25 & 2.0 & 3,500 & 19 & 1.4 & 7 \\
\hline Males & 1,100 & 110 & 34 & 2.5 & 5,950 & 19 & 2.1 & 7 \\
\hline \multirow{2}{*}{\multicolumn{9}{|c|}{ Late winter }} \\
\hline & & & & & & & & \\
\hline \multicolumn{8}{|l|}{ Yearlings: } & 7 \\
\hline Females & 1,000 & 64 & 22 & 2.0 & 3,080 & 17 & 1.1 & 7 \\
\hline Males & 800 & 78 & 26 & 2.0 & 3,640 & 17 & 1.3 & 7 \\
\hline \multicolumn{9}{|l|}{ Adults: } \\
\hline Females & 3,200 & 70 & 24 & 2.0 & 3,360 & 17 & 1.2 & 7 \\
\hline Males & 1,000 & 93 & 30 & 2.0 & 4,200 & 17 & 1.6 & 7 \\
\hline Total & 9,000 & & & & & & & \\
\hline
\end{tabular}

$\mathrm{BMR}=$ basic metabolic rate.

"Approximations based on Alldredge et al. 1974; early-winter values intermediate. between their summer and winter means.

Fawns are not included as grazers in summer.

depleted, but the deer experienced critical weight loss, some becoming manifestly ill. Nagy et al. (1964) estimated that cellulose digestion would be slowed down if the diet contained 15-30\% sagebrush, depending on its oil content. Jobman (1972) suggests $20 \%$ of the diet to be a reasonable approximation of the tolerance of deer for certain junipers, based on relative concentrations and composition of essential oils. In this model we have assumed that deer can consume big sagebrush in quantities up to $20 \%$ of the total diet without impairing digestive efficiency.

\section{Food Requirements}

This discussion emphasizes protein and energy, which are essential for building body tissue and fueling life processes, respectively. Other nutritional entities are requisite to the health of deer, but they are seldom critically limiting to wild populations.

Several studies of deer and similar ruminants provide an adequate approximation of protein requirements (French et al. 1956; Ullrey et al. 1967; Robbins et al. 1974b; and Smith et al. 1975). Verme and Ullrey (1972) concluded that 16-17\% crude protein in the diet would serve the maximum needs of deer,

Table 2. Forage means for estimation of carrying capacity.

\begin{tabular}{|c|c|c|c|c|c|c|}
\hline \multirow[b]{2}{*}{ Season ${ }^{1}$} & \multirow{2}{*}{$\begin{array}{c}\text { Crude } \\
\text { protein } \\
(\%)\end{array}$} & \multirow{2}{*}{$\begin{array}{c}\text { Cell wall } \\
\text { constituents } \\
(\%)\end{array}$} & \multicolumn{2}{|c|}{ Acid detergent fiber } & \multirow{2}{*}{$\begin{array}{c}\text { Dry matter } \\
\text { digestibility } \\
\text { (in vitro) } \\
(\%)\end{array}$} & \multirow{2}{*}{$\begin{array}{l}\text { Est. ME } \\
\text { (kcal/kg) }\end{array}$} \\
\hline & & & $\begin{array}{c}\text { Cellulose } \\
(\%)\end{array}$ & $\begin{array}{l}\text { Lignin } \\
(\%)\end{array}$ & & \\
\hline Summer & 18 & 38 & 16 & 9 & 60 & 2,295 \\
\hline Early winte & ter 7 & 47 & 24 & 16 & 40 & 1,530 \\
\hline Late winter & er 5 & 54 & 38 & 13 & 36 & 1,377 \\
\hline
\end{tabular}

Summer data from July samples, early winter from November, late winter from February; each value is the average for 13 major forages inthe seasonal diet.

Metabolizable energy calculated from GE $(4.5 \mathrm{kcal} / \mathrm{g}) \times$ percent DMD $\times 0.85$. including those of growing fawns and lactating does. Dietz (1965) and Murphy and Coates (1966) suggested that 7\% crude protein is the minimum necessary for maintenance, assuming energy supplies are sufficient so that body protein does not have to be catabolized for energy.

Protein supplies in the summer diet in Middle Park were adequate for optimum growth and lactation (Table 2). Because deer (as well as livestock) apparently are able to select plants and plant parts richer in nitrogen than those sampled by man (Longhurst et al. 1968; Swift 1948; Wier and Torrell 1959), the crude protein values obtained might actually underestimate dietary protein. Therefore, fall protein supplies probably are sufficient for the needs of adult deer, though somewhat deficient for the maximum growth of fawns. But in winter, even allowing for protein selection, deer will be hard pressed to meet the maintenance requirement of $7 \%$ from forage with an average protein content of $5 \%$. To increase protein intake, deer would need to consume more of the highly lignified browse twigs, or more sagebrush along with its toxic essential oils, thereby lowering total digestibility. As an alternative, grass consumption might be increased to increase digestibility, but the diet would be even lower in total protein than a shrub-based diet. This nutritional dilemma is inescapable.

From studies reported by Blaxter (1962), Agricultural Research Council (1965), Silver et al. (1969), and others, Moen (1973) concluded that the basal metabolic rate (BMR) of whitetailed deer is approximately $70 \mathrm{kcal}$ per day per $\mathrm{kg}$ of metabolic weight $\left(\mathrm{W}^{0.75}\right)$. More accurately, this is fasting metabolism of caged deer in a thermoneutral environment. Activity metabolic rate (AMR) is higher because of additional energy needs for thermoregulation, locomotion, gestation, lactation, growth, and gain. Moen (1973) estimated AMR of deer to range normally from 1.23 to 1.98 times BMR, depending on how much 


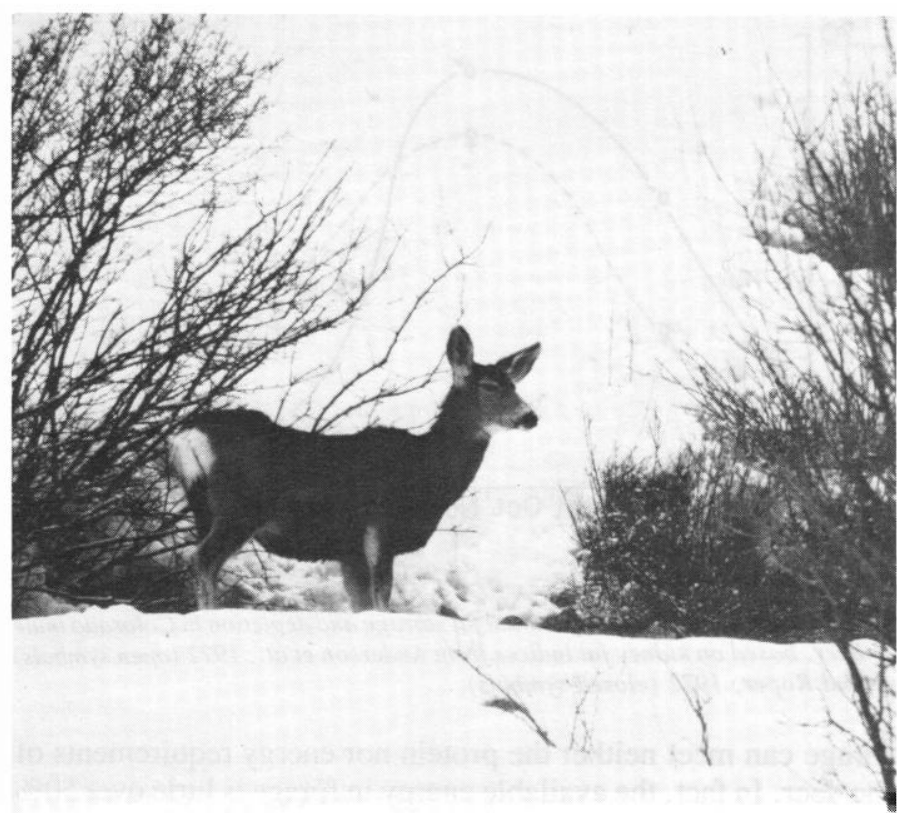

Deer in late stages of winter.

time is spent in various activities; it may reach 2.3 times BMR at the peak of lactation. Caged white-tailed deer subjected to various combinations of temperature and wind treatments exhibited daily metabolic rates ranging up to 3 times BMR in summer and over 2 times BMR in winter (Holter et al. 1975). Maintenance energy requirement of penned mule deer fawns in Middle Park in mid-winter approximated 1.9 times BMR (Carpenter and Baker 1975).

Increased energy demands can, theoretically, be met by increasing food intake. However, deer apparently have limited ability to increase forage intake after the rumen reaches a threshold capacity (Amman et al. 1973). Nagy (1974) reported that food intake and passage rates of mule deer remained essentially constant as fiber content of forage increased. This was attributed to the relatively small size of the digestive organs, suggesting that deer are not well adapted for using high-fiber forage. Because of this limitation, Short (1966) speculated that white-tailed deer may not metabolize browse rapidly enough to supply the necessary calories to maintain body temperature in cold weather.

Nichol (1938) estimated daily intake of penned mule deer and white-tailed deer to be about $1 \mathrm{~kg}$ of air-dry forage per $45 \mathrm{~kg}$ of body weight, or about $22 \mathrm{~g} / \mathrm{kg}$. Alldredge et al. (1974) estimated the average daily forage intake of free-ranging mule deer in northern Colorado from concentrations of fall-out cesium-137 in vegetation and deer muscle tissue. Intake was $21.9 \mathrm{~g} / \mathrm{kg} /$ day for all ages, sexes, and seasons combined. In summer, the average intake of fawns was $31 \mathrm{~g} / \mathrm{kg} / \mathrm{day}$, and of yearlings and adults $21 \mathrm{~g} / \mathrm{kg} /$ day. In winter, intake rate was about $32 \mathrm{~g}$ for fawns (4-10 months) and $17 \mathrm{~g}$ for adults. Yearlings were included as adults at this time. Twenty-monthold deer grazing in a small pasture in Middle Park in February had intakes ranging from 15 to $20 \mathrm{~g} / \mathrm{kg} /$ day (Carpenter and Baker 1975). Explanations for reduced intake in winter can include the possibility that higher intake of poorly digestible forage would overtax the digestive tract, and that energy costs associated with increased intake exceeded energy supply of additional food eaten.

\section{Forage Evaluation Model}

With the foregoing information, a model of the ability of ingested forage to supply the energy needs of deer can be developed from body weight $(\mathrm{W})$, metabolic weight $\left(\mathrm{W}^{0.75}\right)$, activity metabolic rate (AMR), forage intake (INT), gross energy (GE), and dry matter digestibility (DMD). The following example is based on an animal of $70 \mathrm{~kg}(154 \mathrm{lb})$ and AMR factors of 2.5 in summer and 2.0 in winter:

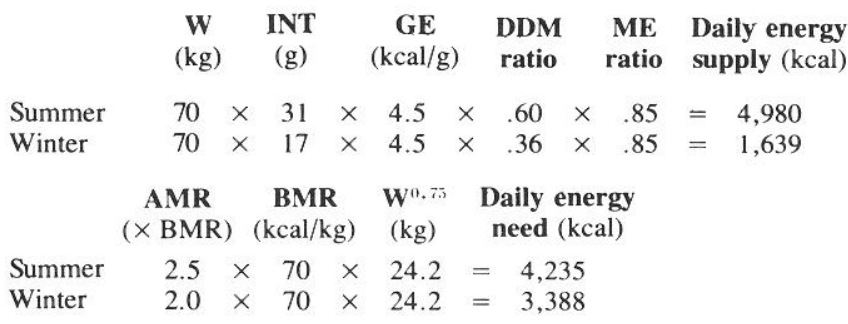

In this case there is an energy surplus in summer available for the synthesis and storage of fat, and a deficit in winter which might be met by catabolizing stored fat and protein. According to Mautz et al. (1976) the net usable caloric yield from catabolized fat is about $6 \mathrm{kcal} / \mathrm{g}$. It would take $292 \mathrm{~g}$ of stored fat to meet the daily energy deficit of $1,749 \mathrm{kcal}$, in the preceding calculation, or $17 \mathrm{~kg}$ of fat over 60 days.

Fat deposits in the skinned, eviscerated carcasses of northern Colorado mule deer as analyzed by Anderson et al. (1972) averaged $16.9 \%$ of the carcass in animals collected between June 23 and September 22, and $13.9 \%$ in those collected between September 23 and December 22. Live weight is roughly $30 \%$ greater than the weight of the skinned, eviscerated carcass, so those figures become about 13 and $11 \%$ fat in the live deer. For a $70-\mathrm{kg}$ deer this is approximately $9 \mathrm{~kg}$ of fat in summer and 8 in autumn. Robbins et al. (1974a) found the fat content of pen-fed white-tailed deer of about $60-\mathrm{kg}$ live weight (excluding ingesta) to be approximately $15 \%$, or $9 \mathrm{~kg}$.

This amount of fat catabolized at the rate of $292 \mathrm{~g} /$ day would be used up in 30 days (assuming no protein catabolism). There is evidence that deer can go beyond this point, however, and still survive. Nagy (1974) and his students, found that mule deer died of starvation when they had lost approximately $30 \%$ of their pre-starvation weight, but they persisted 6 weeks or more without food.

The annual cycle of storage and depletion of fat in Colorado deer is depicted in Figure 2. The additional loss above stored fat is attributable to catabolism of tissue protein and dehydration. Even if the deer does not succumb, however, prolonged winter stress can limit physiological potential and productivity (Wallmo and Gill 1971).

In summer, with an abundance of palatable forages exceeding $70 \%$ digestibility, and crude protein in the range of $15-20 \%$, adequate levels of energy and protein could be obtained even if the metabolism and intake rates used above are inexact. But, among February ranges, the highest digestion coefficient, other than for big sagebrush, was $48.8 \%$ (Agropyron smithii with $3.1 \%$ crude protein) and the highest crude protein content was $6.8 \%$ (Chrysothamnus viscidiflorus with $41.5 \%$ digestibility). Activity metabolic rate was at least $2 \mathrm{BMR}$ because the maintenance requirement in pens was 1.9 BMR. Thus, even if diet digestibility were $45 \%$ and intake $25 \mathrm{~g} / \mathrm{kg} /$ day, yielding approximately $3,000 \mathrm{kcal}$ of metabolizable energy per day, the deer would still have an energy deficit. However, the actual mean digestibility of the diet (in vitro DMD coefficients 
Table 3. Estimation of carrying capacity of seasonal ranges.

\begin{tabular}{|c|c|c|c|}
\hline \multirow[b]{2}{*}{ Measurement } & \multicolumn{3}{|c|}{ Seasonal range } \\
\hline & Summer $\mathbf{F}$ & Early winter L & e winter \\
\hline \multicolumn{4}{|l|}{ Based on forage quantity } \\
\hline $\begin{array}{l}\text { A. Usable forage }\left(\mathrm{kg} \times 10^{6}\right) \\
(=1 / 2 \text { total forage })\end{array}$ & 100 & 31 & 1 \\
\hline $\begin{array}{l}\text { B. Daily deer intake (kg) } \\
\text { (weighted mean) }\end{array}$ & 1.78 & 1.33 & 1.14 \\
\hline C. Deer days of usable forage (ha) & 56.2 & 23.5 & 0.9 \\
\hline D. Season (days) & 160 & 60 & 60 \\
\hline Carrying capacity (C/D) & 350,000 & 390,000 & 14,000 \\
\hline \multicolumn{4}{|l|}{ Based on forage quality } \\
\hline \multicolumn{4}{|l|}{ E. Ratio of protein intake to need } \\
\hline Fawns & n.a. & 0.7 & 0.7 \\
\hline Yearling ? & 1.2 & 1.0 & 0.7 \\
\hline Yearling $\delta$ & 1.2 & 1.0 & 0.7 \\
\hline Adult $P$ & 1.1 & 1.0 & 0.7 \\
\hline Adult $\delta$ & 1.2 & 1.0 & 0.7 \\
\hline \multicolumn{4}{|l|}{ F. Ratio of energy intake to need } \\
\hline Fawns & n.a. & 0.8 & 0.7 \\
\hline Yearling 9 & 1.5 & 0.7 & 0.5 \\
\hline Yearling $\delta$ & 1.5 & 0.6 & 0.5 \\
\hline Adult + & 0.9 & 0.6 & 0.5 \\
\hline Adult ${ }^{\star}$ & 1.1 & 0.5 & 0.5 \\
\hline Carrying capacity & 350,000 & 0 & 0 \\
\hline
\end{tabular}

weighted by diet composition) was $36.3 \%$ and estimated intake rates were $15-20 \mathrm{~g} / \mathrm{kg} / \mathrm{day}$, which results in a very substantial deficit.

\section{Implications to Range Evaluation}

Grazing capacity is customarily defined as the number of animals the range can support on a sustained basis-that is, without degradation of the range vegetation. For the present discusion we will assume that $50 \%$ use of the total forage supply is tolerable, and we will estimate carrying capacity from (a) the supplies of forage, (b) the intake limitations of deer, (c) the requirements of deer for the primary nutrients - protein and chemical energy, and (d) the availability of those nutrients in forage.

Approximations of those parameters are presented in Tables 1 and 2 , and carrying capacity is calculated in Table 3 . The calculations are based on the assumptions that all of the forage protein is digestible, that percent digestibility of gross energy equals percent digestibility of total dry matter, in vitro, and that $85 \%$ of the digestible energy is metabolizable.

Forage on the summer range meets the nutritional needs of deer, so winter forage supplies determine carrying capacity. Apparently the summer range could support about 350,000 deer, or $70 \mathrm{deer} / \mathrm{km}^{2}\left(180 \mathrm{deer} / \mathrm{mi}^{2}\right)$. Expressed in animal-unit equivalence to livestock adapted from figures published by the Texas Agr. Exp. Sta. (1957) this corresponds to about 14 animal units per km ${ }^{2}$. In the Rocky Mountain region the Forest Service considers 4-8 acres per animal-unit-month (20-40 acres per animal unit for a 5-month season) to be reasonable grazing pressure for this type of range; that is, 6-12 animal units per $\mathrm{km}^{2}$, which is equivalent to $30-60$ deer. Thus, in the context of range management experience, the carrying capacity estimate is large, but not implausible.

In terms of forage quantity the early-winter range has comparable capacity $(\sim 390,000)$. In terms of quality that forage might nearly meet protein needs but would provide only $2 / 3$ of the herd's energy needs. Figure 2 suggests a rapid drop in deer fat deposits during this period. On late-winter range, forage quantity is calculated to be adequate for 14,000 deer, but that

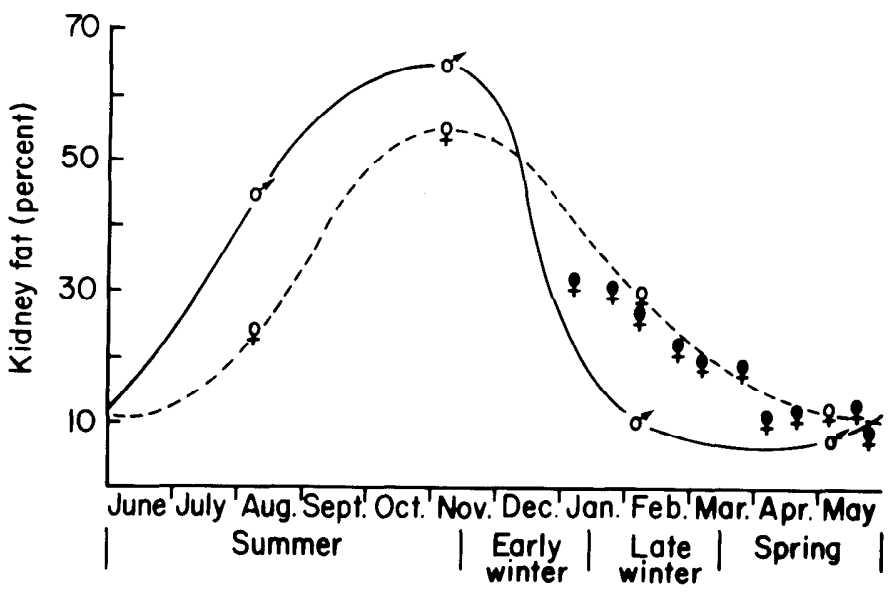

Fig. 2. Postulated curves of annual fat storage and depletion in Colorado mule deer, based on kidney fat indices from Anderson et al., 1972 (open symbols) and Roper, 1972 (closed symbols).

forage can meet neither the protein nor energy requirements of the deer. In fact, the available energy in forage is little over $50 \%$ of the estimated requirement.

In open, short winters in Middle Park, when there is more forage accessible and more opportunity for selection, mortality has been low and ensuing natality high. The number of deer that can survive under those conditions might be accepted as a management goal. Still, at or below that population level, overwinter mortality rates will be governed not by the potential of the total forage resource to support deer, but by snow conditions (which determine the energy cost for the energy gained from grazing) and by the duration of the winter. Thus, as concluded by Wallmo and Gill (1971:7), "the concept of a stable carrying capacity for deer in the high valleys of the central Rockies is unrealistic."

\section{Implications for Management and Research}

Raleigh (1970:108) said, “The first requirement in developing a range livestock and forage management program is a quantitative and qualitative inventory of forage resources. This means an inventory of range forage nutrients. . . ." This requirement applies just as logically to big game herds and their habitat. Procedures that qualify and quantify supplies of forage nutrients will offer a better basis for assessing the adequacy of habitat than those that provide information on current growth and use of a few "key" species that really are not key to the nutritional needs of deer.

Methods for assessing forage nutrients and forage biomass are available, though they have never been applied to range evaluation on an extensive scale. Continuing research in Middle Park is concerned with (1) refinement of the estimates of metabolic requirements of deer, (2) methods for mitigating winter nutritional deficiencies, including forage improvement and snow management, and (3) development of practical forage inventory procedures. In many cases, there may be small latitude for forage improvement on winter range. Nonetheless, knowledge of the factors that limit carrying capacity clarifies the options open to management and provides more rational direction for research.

\section{Literature Cited}

Agricultural Research Council. 1965. The nutrient requirements of farm livestock. No. 2. Ruminants. H.M. Stationery Office, London. 264 p. 
Alldredge, A. W., J. F. Lipscomb, and F. W. Whicker. 1974. Forage intake rates of mule deer estimated with fall out cesium-137. J. Wildl. Manage. 38:508-516

Amman, A. P., R. L. Cowan, C. L. Mothershead, and B. R. Baumgardt. 1973. Dry matter and energy intake in relation to digestibility in white-tailed deer. J. Wildl. Manage. 37:195-201.

Anderson, A. E., D. E. Medin, and D. C. Bowden. 1972. Indices of carcass fat in a Colorado mule deer population. J. Wildl. Manage. 36:579-594.

Association of Official Agricultural Chemists. 1955. Official methods of analysis. 8th Ed. Washington, D.C. 1008 p.

Blaxter, K. L. 1962. The energy metabolism of ruminants. Hutchison and Co., London. $332 \mathrm{p}$.

Brody, S. 1945. Bioenergetics and growth. Reinhold Publishing Co., New York. 1023 p.

Carpenter, L. H. 1972. Middle Park deer study_range fertilization. p. 211251. In: Game Res. Rep. July 1972, Part Two. Colorado Div. Wildl., Denver.

Carpenter, L. H., and D. L. Baker. 1975. Middle Park cooperative deer study - deer habitat evaluation. p. 243-263. In: Game Res. Rep. July 1975. Part Two. Colorado Div. Wildl., Denver.

Cook, C. W. 1971. Effects of season and intensity of use on desert vegetation. Utah State Univ. Agr. Exp. Sta. Bull. 483. 57 p.

Dietz, D. R. 1965. Deer nutrition research in range management. Trans. North Amer. Wildl. and Nat. Resour. Conf. 30:274-285.

French, C. E., L. C. McEwen, N. D. Magruder, R. H. Ingram, and R. W. Swift. 1956. Nutrient requirements for growth and antler development in the white-tailed deer. J. Wildl. Manage. 20:221-232.

Gilbert, P. F., O. C. Wallmo, and R. B. Gill. 1970. Effect of snow depth on mule deer in Middle Park, Colorado. J. Wildl. Manage. 34:15-23.

Gill, R. B. 1969. Middle Park deer study—population density and structure. p. 105-122. In: Game Res. Rep. July 1969, Part Onc. Colorado Div. Wildl., Denver.

Gill, R. B. 1970. Middle Park deer study_productivity and mortality. p. 337 354. In: Game Res. Rep. July 1970, Part Two. Colorado Div. Wildl., Denver.

Gill, R. B., and O. C. Wallmo. 1973. Middle Park deer study-physical characteristics and food habits. p. 81-103. In: Game Res. Rep. July 1973, Part Two. Colorado Div. Wildl., Denver.

Holter, J. B., W. E. Urban, Jr., H. H. Hayes, H. Silver, and H. R. Skutt. 1975. Ambient temperature effects on physiological traits of white-tailed deer. Can. J. Zool. 53:679-685.

Jobman, W. G. 1972. Consumption of juniper by deer and inhibition of rumen microorganisms by volatile oils of juniper. MS Thesis, Colorado State Univ., Fort Collins. $51 \mathrm{p}$.

Longhurst, W. M., H. K. Oh, M. B. Jones, and R. E. Kepner. 1968. A basis for the palatability of deer forage plants. Trans. North Amer. Wildl. and Nat. Resour. Conf. 33:181-189.

Mautz, W. W., H. Silver, and H. H. Hayes. 1974. Predicting the digestibility of winter deer browse from its proximate composition. Can. J. Zool. 52:1201-1205.

Mautz, W. W., H. Silver, J. B. Holter, H. H. Hayes, and W. E. Urhan, Jr. 1976. Digestibility and related nutritional data for seven northern deer browse species. J. Wildl. Manage. 40:

McLeod, M. N., and D. J. Minson. 1974. Predicting organic-matter digestibility. J. Brit. Grassl. Soc. 29:17-21.

Moen, A. N. 1973. Wildlife ecology, an analytical approach. W. H. Freeman and Co., San Francisco. 458 p.

Moir, R. J. 1961. A note on the relationship between the digestible dry matter and digestible energy content of ruminant diets. Aust. J. Exp. Agr. and Anim. Husb. 1:24-26.

Murphy, D. A., and J. A. Coates. 1966. Effects of dietary protein on deer. Trans. North Amer. Wildl. and Nat. Resour. Conf. 31:129-139.

Nagy, J. G. 1974. Physiology and prevention of deer starvation. p. 395-554. In: Game Res. Rep. July 1974, Part Three. Colorado Div. Wildl., Denver.

Nagy, J. G., H. W. Steinhoff, and G. M. Ward. 1964. Effects of essential oils of sagebrush on deer rumen microbial function. J. Wildl. Manage. 28:785-790.

Nichol, A. A. 1938. Experimental feeding of deer. Univ. of Arizona Agr. Exp. Sta. Bull. 75.39 p.
Pearson, H. A. 1970. Digestibility trials: In vitro techniques. p. 85-92. In: Range and wildlife habitat evaluation-a research symposium. U.S. Dep. Agr. Misc. Pub. 1147. 220 p.

Raleigh, R. J. 1970. Symposium on pasture methods for maximum production in beef cattle: manipulation of both livestock and forage management to give optimum production. J. Anim. Sci. 30:108-114.

Rittenhouse, L. R., C. L. Streeter, and D. C. Clanton. 1971. Estimating digestible energy from digestible dry and organic matter in diets of grazing cattle. J. Range Manage. 24:73-75.

Robbins, C. T. 1973. The biological basis for the determination of carrying capacity. $\mathrm{PhD}$ Thesis, Cornell Univ., Ithaca. $239 \mathrm{p}$.

Robbins, C. T., A. N. Moen, and J. T. Reid. 1974a. Body composition of white-tailed deer. J. Anim. Sci. 38:871-876.

Robbins, C. T., R. L. Prior, A. N. Moen, and W. J. Visek. 1974b. Nitrogen metabolism of white-tailed deer. J. Anim. Sci. 38:186-191.

Roper, L. A. 1972. Middle Park deer study-physical characteristics and food habits. p. 199-209. In: Game Res. Rep. July 1972, Part Two. Colorado Div. Wildl., Denver.

Ruggiero, L. F., and J. B. Whelan. 1976. A comparison of in vitro and in vivo digestibility by white-tailed deer. J. Range Manage. 29:82-83.

Scales, G. H., C. L. Streeter, A. H. Denham, and G. M. Ward. 1974. A comparison of indirect methods of predicting in vivo digestibility of grazed forage. J. Anim. Sci. 38:192-199.

Short, H. L. 1966. Effects of cellulose levels on the apparent digestibility of feeds eaten by mule deer. J. Wildl. Manage. 30:163-167.

Silver, H., N. F. Colovos, J. B. Holter, and H. H. Hayes. 1969. Fasting metabolism of white-tailed deer. J. Wildl. Manage. 33:490-498.

Smith, G. E. 1971. Energy metabolism and metabolism of the volatile fatty acids. p. 543-562. In: The Digestive Physiology and Nutrition of Ruminants. Vol. 2 Nutrition. D. C. Church, Corvallis, Ore. 801 p.

Smith, S. H., J. B. Holter, H. H. Hayes, and H. Silver. 1975. Protein requirements of white-tailed deer fawns. J. Wildl. Manage. 39:582-589.

Swift, R. W. 1948. Deer select most nutritious forage. J. Wildl. Manage. 12:109-110.

Swift, R. W. 1957. The caloric value of TDN. J. Anim. Sci. 16:753-756.

Texas Agricultural Experiment Station. 1957. Livestock and deer ratios for Texas range lands. Texas Agr. Exp. Sta. MP-221, College Station. 9 p.

Thompson, C. G., J. B. Holter, H. H. Hayes, H. Silver, and W. E. Urban, Jr. 1973. Nutrition of white-tailed deer. I. Energy requirements of fawns. J. Wildl. Manage. 37:301-311.

Tilley, J. M. A., and $\bar{\kappa}$. A. Terry. 1963. A two-stage technique for in vitro digestion of forage crops. J. Brit. Grassl. Soc. 18:104-111.

Ullrey, D. E., W. G. Youatt, H. E. Johnson, L. D. Fay, and B. L. Bradley. 1967. Protein requirements of white-tailed deer fawns. J. Wildl. Manage. 31:679-685.

Van Soest, P. J. 1963. Use of detergents in the analysis of fibrous feeds. II. A graphic method for the determination of fiber and lignin. Ass. Offic. Agr. Chem. J. 46:829-835

Van Soest, P. J., and R. H. Wine. 1967. Use of detergents in the analysis of fibrous feeds. IV. Determination of plant cell-wall constituents. Ass. Offic. Anal. Chem. J. 50:50-55.

Verme, L. J., and D. E. Ullrey. 1972. Fecding and nutrition of deer. p. 275291. In: The Digestive Physiology and Nutrition of Ruminants. Vol. 3 Practical Nutrition. D. C. Church, Corvallis, Ore. 350 p.

Wallmo, O. C., and R. B. Gill. 1971. Snow, winter distribution, and population dynamics of mule deer in the central Rocky Mountains. Snow Ice Relation Wildl. Recreation Symp. Proc. [Ames, lowa, Feb. 11-12, 1971]. $1-15$.

Wallmo, O. C., W. L. Regelin, and D. W. Reichert. 1972. Forage use by mule deer relative to logging in Colorado. J. Wildl. Manage. 36:1025-1033.

Ward, G. M., and J. G. Nagy. 1966. Bacterial inhibition by the essential oils of sagebrush. Colorado State Univ. Final Rep. to the Natl. Sci. Found. on Grant No. GB1507. 54 p. Processed.

Wier, W. C., and D. T. Torrell. 1959. Selective grazing by sheep as shown by a comparison of the chemical composition of range and pasture forage obtained by hand-clipping and that collected by esophageal fistulated sheep. J. Anim. Sci. 18:641-649 